\title{
36. 腎臓常温灌流保存装置の開発
}

\author{
壁井信之*山田明夫* 桜井靖久* \\ 土屋喜一*2 春日幸夫皮 ${ }^{* 3}$ 小原正三*8
}

\section{目的}

臓器保存法には常温灌流保存, 低温 灌流保 存, 凍結保存などがあるが，現在血液を使用せ ず，また灌流条件が多少生理的でなくとも代謝 の抑制で代償できる利点を持つ低温灌流保存法 が主流となっている。これに引替え常温保存法 は，低温に比し10倍以上の代謝速度となり，灌 流法が生理的条件に十分合致しなければ，たち まちにして循環不全状態に陥り，数時間内に組 織の変性が生じるため，その問題点の難しさか ら敬遠されてきた。

しかし常温灌流保存法は低温灌流法より，よ り生理的になりうることから，長期保存の可能 性を秘め, かつ将来の臟器レベルの医学研究に 有力な手段となると考えられるので, 新たにそ の可能性を追求す心゙く，灌流装置を開発し，動 物実験により灌流方法などの基礎的検討を試み た.

\section{装}

血液をできるだけ変性させずに灌流を行いう る装置が必要となることから，図1に示すよう な血液ポンプ, 圧波形整形装置, 熱交換器, 人 工肺を構成要素とした常温血液灌流システムの 開発を行った。

ポンプは 1 回拍出量が数 $\mathrm{m} \ell$ 以下ときわめて 小型となること，ポンプ内での凝血を防ぐ，減 菌のため回路全体をディスポーザブル化し易い ことなどの点から，従来の人工弁を有する拍動

\footnotetext{
* 東京女子医科大学医用工学研究施設

*2 早稲田大学理工学部機械工学科

*3 日機装珠
}

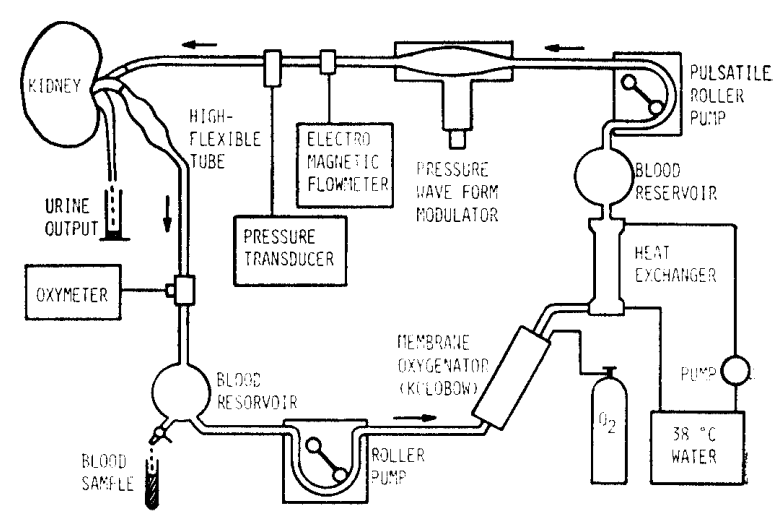

図 1 租臓常温篗流保存システム

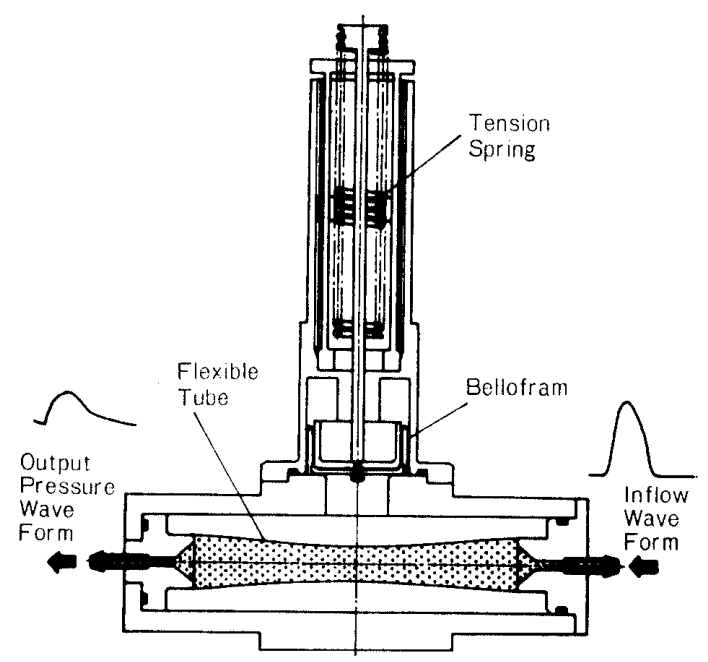

図 2 圧波形整形蓄置

型ポンプの代りに，回転子を間歇的に回転させ 拍動流を得るローラ型拍動ポンプとした。ポン プは拍動数60〜200bpm, 駆血時間 $0 \sim 140 \mathrm{ms,}$ 分時拍出量 $0 \sim 300 \mathrm{~m} \ell / \mathrm{min}$ の間で可変であり, また通常の平滑流にすることも可能である. 圧 波形整形装置（図 2) はポンプからの駆出波形 を管路のキャパシタンス変化により, 任意の波 
形に変化させる機能を持ち，腎臓を灌流するの に適した波形を得るための装置である。熱交換 器はBrown-Harison 型を血流量 $200 \mathrm{~m} \ell / \mathrm{min}$ 以 下で100の熱交換効率が得られるように改良し， 局所的温度上昇による血液成分の変性が生じな い上う留意した。 人工肺もKolobow型膜型肺を 使用し，蛋白変性をできるだけ抑えるようにし た.

\section{基 礎 実 験}

a : ポンプ溶血試験

腎臟を長時間灌流する際にはポンプによる溶 血が大きな影響を与えるものと考えられ，in vitro で犬の血液を用い，負荷側にシリコーン ゴム製の球形りザーバを取り付け回路内総充 填血液量 $400 \mathrm{~m} \ell$, 一マトクリット 37 , 流量 300 $\mathrm{m} \ell / \mathrm{min}$ で20時間連続運転し，溶血度を測定し た.

\section{結果}

図 3 にその結果を示す。時間, 溶血量とも対 数で表わした場合，その関係は直線となり，時 間とともに指数関数的に溶血が増加している が，試験条件が実際の腎血流量の 3 倍以上であ ることを考えると，1日程度の灌流実験には， このポンプを使用してさしつかえないものと思 われる。

\section{b : 脈動流と平滑流の比較}

灌流血圧波形が腎機能にどのような影響を与 えるか体重 $15 \mathrm{~kg}$ 前後の雑種成犬 8 頭を 2 群に別 けて検討を行った。第 1 群は大腿動脈から脱血

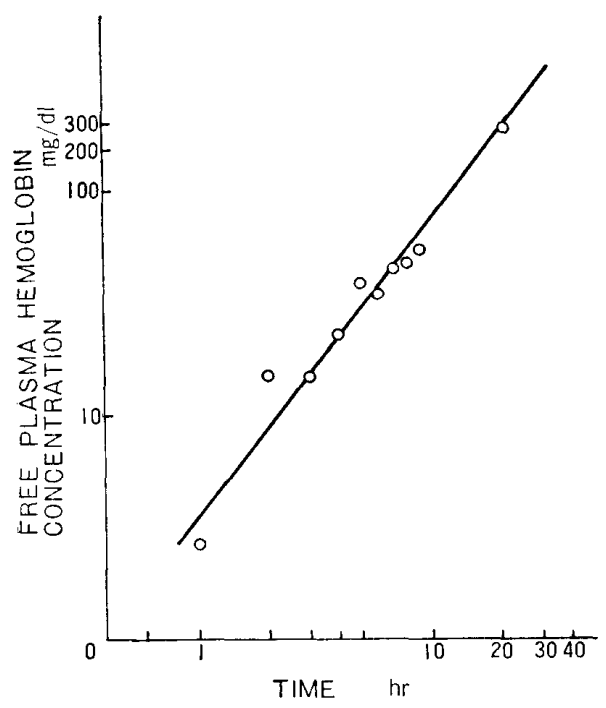

図 3 溶血試験結果

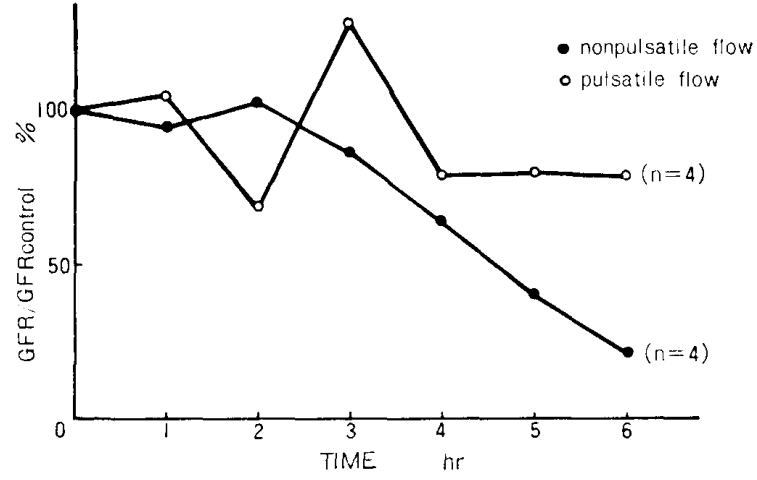

図 4 脈動流と平滑流の堅機能に及ほす影留の比較

し，シリコーンチューブを用いた管路㐨よび圧 波形整形装置を通し腎動脈に送血するバイパス 回路を作製し，生体の動脈圧波形をできるだけ 歪ませずに腎臓の灌流を行った。またバイパス 回路が挿入されていない，もう一方の腎臓の機 能を対照として使用し，手術侵襲の影響を相殺 するようにした，第 2 群は同じバイパス回路を 用い圧波形整形装置のキャパシタンスを大きく し, 脈圧が $5 \mathrm{mmHg}$ 以下になるまで平滑化し て灌流を行い腎機能変化を測定した。

\section{結 果}

困4 は腎機能をGFR で評価したもので対照 側の腎の GFRを $100 \%$ として 4 例の平均值を示 した。両群とも 2 時間までは，ほぼ正常に近い 值を維持しているが，3 時間以上では生体の脈 圧を維持して灌流した群では GFR の滅少はわ ずかであったにもかかわらず，平滑化して灌流 した群では徐々に GFR は減少し 6 時間後には 灌流前の30\%以下にまで低下した。このことか ら腎臓を常温灌流する際には拍動流が有利であ ると思わ机る。

\section{c：ポンプによる灌流の影響}

$15 \mathrm{~kg}$ 前後の雑種成犬 6 頭を用い, 前述のバイ パス回路にポンプを挿入して灌流を行い，血液 の酸素化や代謝面はすべて生体に依存し，ポン プによる灌流の影響だけを検討するようにし た.

\section{結果}

初期の 4 例では， $50 \mathrm{~m} \ell / \mathrm{min}$ 以下の低流量域 で1回拍出量のコントロールが正確に行えず平 均圧, 脈圧が大幅に変動したため GFR は極端 に低下し，病理所見でもかなりの異常が認めら 


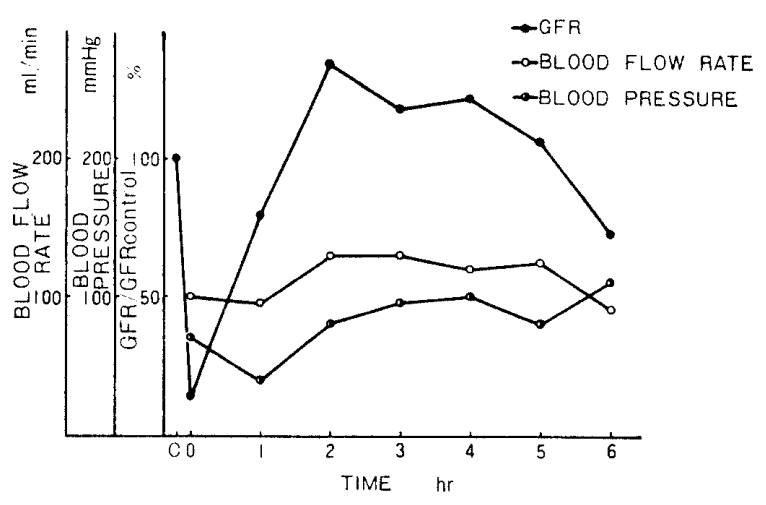

図 5 拍動流ポンプによる萑流の影表

れた，後の 2 例はこの点に関し改良を加えたポ ンプで灌流を行ったもので，その結果を図 5 に 示す. 灌流開始直後GFR は極端に低下寸るが, これは虚血時間があったためで30分以内に正常 域に復帰し, 以後 6 時間まで GFR は正常域か ら大幅に低下することはなかった。また病理検 查では循環不全時に生ずる変化を示したが，い ずれも可逆的変化にとどまり生体心による灌流 の結果より多少悪い程度であった。

\section{腎臓常温灌流保存実験}

以上の実験から開発した拍動ポンプで 6 時間 程度なら十分腎機能を維持できると考え図 1 に 示した灌流システムを用い, へマトクリット25 \%の稀釈血液による常温灌流保存を行った。

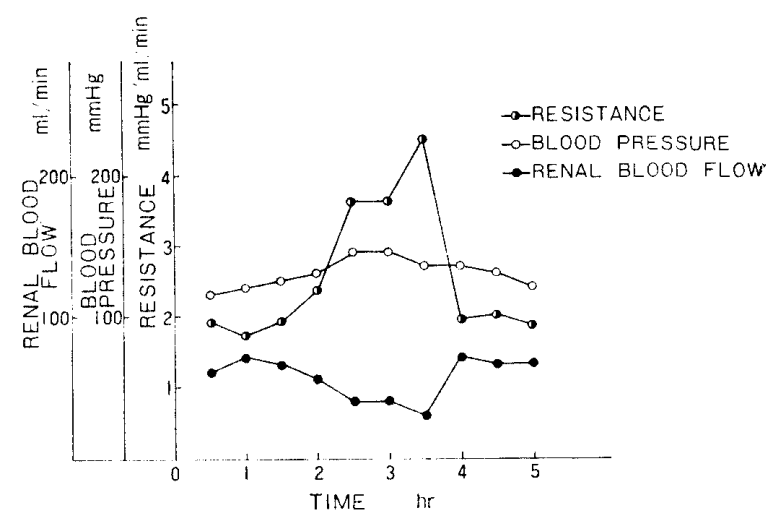

図 6 骨常温灌流保存中の血行動龍

\section{結 果}

図 6 にその血行動態を示す。腎血管抵抗は 3 時間半まで徐々に上昇した後, 急激に減少し以 後 6 時間まで一定であった。これは腎血管系に シャントが生じたためと考えられる。またGFR もきわめて低く，病理所見も可逆ではあるが高 度の循環不全状態を示し, 灌流が適切に行われ なかったと思われる。

\section{ま亡め}

以上の結果から，腎臟の常温灌流保存では， 灌流圧波形および灌流血液の性状が大きな影響 を与えることが分かったが今後さらに詳細な検 討が必要と思われる. 